University of Nebraska - Lincoln DigitalCommons@University of Nebraska - Lincoln

U.S. Air Force Research

U.S. Department of Defense

2013

Inaction speaks louder than words: The problems of passivity

Sally J.F. Baron

United States Air Force Academy

Follow this and additional works at: http:// digitalcommons.unl.edu/usafresearch

Baron, Sally J.F., "Inaction speaks louder than words: The problems of passivity" (2013). U.S. Air Force Research. 42.

http://digitalcommons.unl.edu/usafresearch/42

This Article is brought to you for free and open access by the U.S. Department of Defense at DigitalCommons@University of Nebraska - Lincoln. It has been accepted for inclusion in U.S. Air Force Research by an authorized administrator of DigitalCommons@University of Nebraska - Lincoln. 


\title{
Inaction speaks louder than words: The problems of passivity
}

\author{
Sally J.F. Baron
}

United States Air Force Academy, 2354 Fairchild Drive, United States Air Force Academy, CO 80840-6208, U.S.A.

\author{
KEYWORDS \\ Whistleblower; \\ Crisis management; \\ Player; \\ Bystander; \\ Sports; \\ Joe Paterno; \\ Vancouver Olympics
}

\begin{abstract}
Much has been written about bystander apathy, which occurs when an outsider (i.e., the bystander) is hesitant to act during a situation that clearly calls for action. However, what about when the individual called to act is an insider? This article asserts that insiders (i.e., players, or organizational actors) exhibit similar passive behaviors but not because they are apathetic. Players who are internal to the organization and are often responsible for the outcome are expected to act. Rather, when confounded by ambiguous situations, obfuscated communications, time pressure, and confusion, players often stand by befuddled. This article surveys two such cases. First is the recent case of Joe Paterno, the famed and beloved Penn State football coach of 62 years whose otherwise remarkable career was tainted by his failure to adequately act following a child abuse allegation of a staff member. Second is the case of the Vancouver Olympic Committee and the death of a young athlete on their newly built luge run. Those responsible failed to act when the danger of the track's extreme speeds were well known. The article compares the two cases and concludes by proposing remedies to mitigate inaction.

(C) 2013 Kelley School of Business, Indiana University. Published by Elsevier Inc. All rights reserved.
\end{abstract}

\section{What are we thinking?}

What are we thinking? Sometimes, we're not; we're reacting instead. Sometimes, we are victims of our own evolutionary success and fixed-action patterns that have kept us safe (Cialdini, 2009). In modern society, these behaviors still prevail. Many of us fear snakes-a behavior that saved the lives of our

E-mail address: sally.baron@usafa.edu ancestors. Similarly, we are inclined to stay away from trouble. These heuristics help us get safely through our days without requiring complicated analysis and deep thought for each situation, but sometimes, we need to involve ourselves in troublesome situations for the sake of humanity, overriding our natural instincts. The applications for more effective behavior in crisis situations are widespread. In war zones, natural disasters, accidents, and even sports, effective crisis management happens one person at a time. The actions of a single person or many 
individuals working together can have enormous effects on outcomes. This article examines such responses to extreme situations.

Stunned, shocked, scared, and confused, human beings often act like the proverbial deer frozen in the headlights when presented with a troublesome and unprecedented situation. Organizational actors, who are often a very important part of systems potentially going foul, often stand by in confusion or with the assumption that with so many people around, someone must be doing something. These can include situations with outcomes having devastating effects, such as loss of life. For the organizational actor, speaking up or acting in any way out of the norm could be risky behavior, placing the actor as well as his/her reputation, job, and livelihood in jeopardy. In the midst of confusion, people are hesitant to stand out for fear of potentially making an embarrassing mistake or looking foolish in front of others. According to the theory of social proof, people take cues from others and follow suit (Cialdini, 2009). There is no strong evidence suggesting people are apathetic; it just appears that way. Some studies have suggested a diffusion of accountability causes people to react with ambivalence, especially if the situation is ill defined (Darley \& Latané, 1968).

\subsection{Bystanders, players, and stages of inaction}

The distinction between bystander apathy and player inaction requires clarification. A bystander is a person uninvolved with or outside an organization or situation. A player is a person involved with or inside an organization or situation. Apathy is not caring, while inaction is simply not acting. Let's look at a specific and well-known case and then examine the problems of passivity.

\section{Joe Paterno}

By most measures, the late Joe Paterno was an extraordinary person as his career and personal successes remain unparalleled. With a total of 62 years' coaching at Penn State, and 45 years as head coach, Paterno had a remarkable football career. Not the typical path for someone with an English literature degree from an Ivy League college, the famous football coach was also a supporter of intellectual endeavors and higher education. When Paterno arrived at Penn State in 1950 as an assistant coach, the Nittany Lions football team was hardly a top contender. Since taking the head coaching position in 1966, Paterno led them to 37 bowl games and was named the winningest Division I coach in the history of the sport with 409 victories under his belt (Carey, 2012).

His players, friends, fans, and family adored him. He was married to Suzanne [née] Pohland, and they spent 50 years together. They raised five children, all Penn State graduates, and enjoyed the love of 17 grandchildren. During his tenure at Penn State, Paterno turned down several substantially more lucrative offers to coach professional football. He liked to reminisce about his father's words: that money is needed to live, but too much is simply unnecessary. His coaching style blended academics, athletics, and ethics. His philosophy bled into campus life, and he was considered a positive force throughout the enormous campus. His family donated millions of dollars to Penn State, and the Paterno Library has stood as a symbol of his commitment and generosity. He was affectionately nicknamed JoePa and was an endeared and beloved figure on the Penn State campus.

People who knew Joe well remarked that he was adored and outspoken but not perfect or saintly. As with many successful coaches, Paterno was intense and was known to shout at his players and others. His outspoken nature and passion to improve his team and moreover Penn State often offended others. Friction with the university over the punishment of players who broke school rules was not uncommon. As a coach, he got much satisfaction out of rehabilitating players who needed guidance. He was a man of many interests who believed strongly in a well-rounded education and liked the challenge of helping an athlete who was having trouble academically or otherwise. He was always anxious to support such athletes even if he had to clash with university officials.

In October 2011, one of Paterno's former assistant coaches, Jerry Sandusky, came under fire for some 50 counts of sexual assault against eight boys over a 15-year period. Sandusky left Penn State in 1999 after Paterno told him that his chances for advancement were nil. After investigations, it was discovered that in 2002, Paterno was made aware of one of these alleged attacks by a member of his staff, Mike McQueary, then an assistant coach (Everson, 2012). McQueary reported that he witnessed Mr. Sandusky's suspicious behavior in the football facilities. In 2002, Sandusky was three years gone from Paterno's staff, but Paterno reported what he knew of the incident to his superiors, including the athletic director and, later, the university vice president of finance and business, who oversaw the university police. Paterno said that he was not accustomed to handling such situations and was satisfied that he had adequately acted to report the allegations made about his former employee. 
Surely, his hierarchy and their legal staff would understand what to do under such strange circumstances.

Few people would argue that Paterno was not only a hard-working and successful coach but that he also had an enviable and successful family life. However, in an unprecedented situation, success worked against him, and a betrayal of one of his trusted staff was surely unparalleled. He always did what he thought was right, and he was often successful. In the alleged sexual assault cases, he also did what he thought was right: report it to the authorities, thinking they will take care of it. There's nothing at all illogical about that; after all, Sandusky no longer worked for him.

In his last interview ever, with Sally Jenkins (2012) of The Washington Post, some of Paterno's actions could be better understood: "I didn't know exactly how to handle it, and I was afraid to do something that might jeopardize what the university procedure was," he said. "So I backed away and turned it over to some other people, people I thought would have a little more expertise than I did. It didn't work out that way." He reiterated that McQueary was unclear with him about the nature of what he saw and added that even if McQueary had been more graphic, he was not sure he would have comprehended it: "You know, he [McQueary] didn't want to get specific," Paterno said. "And to be frank with you, I don't know that it would have done any good because I never heard of. . .rape and a man. So I just did what I thought was best. I talked to people that I thought. . .if there was a problem. . .would [follow] up on it." Paterno later remorsed, "I grieve for the children and their families, and I pray for their comfort and relief." When asked the obvious of why he did not do more, he replied, "I didn't know exactly how to handle it."

Academic literature is rich in examining this type of seemingly apathetic behavior. It has revealed people are not apathetic; they are simply befuddled by their situation. Paterno's words allude to his confusion. He knew he needed to act but did not know how. He acted according to what he understood, assuming that his superiors were better equipped to deal with it than he. Although he immediately reported McQueary's allegations to Penn State Athletic Director Tim Curley, in the end, he wished he had acted further: "With the benefit of hindsight, I wish I had done more," said Paterno in a November 9, 2011, interview with The Wall Street Journal (Gay, 2012).

The court case concluded in June 2012 as many shocking facts emerged. As early as the 1994-1995 season, Sandusky assaulted Victim 6, but it was not until 1998 that the victim's mother became suspicious after her then 11-year-old arrived home with wet hair after showering with Sandusky. She reported the incident to university police, who, along with Jerry Lauro from the Pennsylvania Department of Public Welfare, interviewed Sandusky. Though Sandusky admitted wrongdoing to both the public officials and the boy's mother, there were no criminal charges.

In the fall of 2000, another adult bore witness to child abuse. James Calhoun, a temporary custodian saw Sandusky performing oral sex on a boy. The boy was reported to be between the age of 11 and 13 and later became known as Victim 8. Calhoun immediately reported the incident to his supervisor, who asked him to report it to another official. Calhoun left his job without making another report. One of Calhoun's co-workers, Ronald Petrosky, witnessed a similar incident but did not report it. Paterno fired Sandusky from his staff in June 1999, but Sandusky, with emeritus status, still had access to the Penn State locker room, which made his chain of command unclear.

It was not until March 1, 2002, that Mike McQueary, a graduate assistant who would become central to the case as the only whistleblower, witnessed Sandusky sexually abusing a pre-teen boy, later known as Victim 10. McQueary spoke with his father that evening and then reported the incident to Coach Joe Paterno the following day. On March 3, Paterno reported what he heard to Athletic Director Tim Curley. Later that month, McQueary was called to meet with Curley and Senior Vice President for Finance and Business Gary Schultz, who had the university police under his charge (Kingkade, 2011). Curley and Schultz assured McQueary that they would investigate his allegations. Before the month was out, Curley assured McQueary that Sandusky's locker room privileges had been revoked.

As the case unfolded, details emerged, and they will continue to surface over the next few years. Were there other players who did not act at all? What is known for certain is that there were numerous counts of inaction at many levels of responsibility. Those who are known to have not acted responsibly have been dismissed, including the university president. No two levels of inaction are alike, and the combinations are nearly infinite. For simplicity, they have been consolidated into four levels:

- Stage I. Player inaction is the failure of an organizational actor (i.e., the player) to intervene in a situation in which he/she could prevent it from deteriorating further. The player observes a situation calling for action and simply does nothing. 
Figure 1. Stages of Inaction

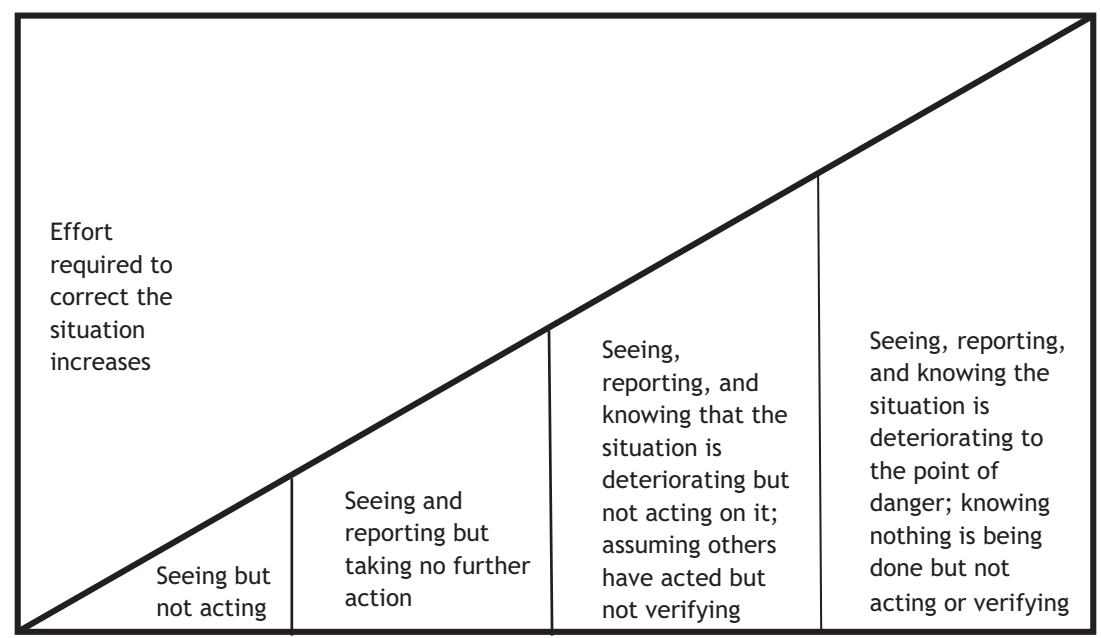

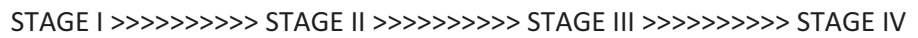

Situation degrades over time $\rightarrow$

- Stage II. The player may say something or report the incident, but his/her actions are ultimately ineffective.

- Stage III. The player fails to ensure adequate action is taken once the player has spoken up. In this stage, the player may well act but fails to follow through and does not ensure that anything is rectified.

- Stage IV. The player has acted and is cognizant of the situation degrading. The player may have spoken up and followed up but not effectively, and the situation deteriorates as the player stands by dumbfounded.

Figure 1 depicts the four stages and diagrams the required increased commitment to the situation as time moves forward. When players choose to ignore a situation, it becomes more difficult to act as time goes on. They become committed to their original course of inaction and flow with the situation's momentum as it degrades.

According to the theories of commitment and consistency (Cialdini, 2009), organizational actors who find themselves in Stage I and remain passive will continue to remain passive, not wanting to go against their original choice. It is impossible to tell how many people were stuck in Stage I because, by definition, they did nothing. Did other people witness abuse? In a locker room full of activity, it is hard to imagine that they did not. Did parents ignore the signs of abuse? There were more than 50 incidents, but to date, only one was reported by a concerned mother.

\subsection{Sensemaking: What went wrong?}

As early as 1998, Pennsylvania public officialscharged with the safety of its citizens-became stuck in Stage II. Although they were aware of child abuse, they did not act effectively. Simply put, releasing the perpetrator without criminal charges was wrong. As a result of their inaction, many other boys would be abused over the next decade. Further, unprecedented, ambiguous, misunderstood, unclear, and obfuscated, Paterno knew there was wrongdoing that had taken place on his watch, reported it to the authorities, and believed his actions were adequate. Clearly, Paterno knew he had to do something about what he knew, so he reported it to his chain of command-speaking up, Stage II. However, he was caught in Stage III, and his failure to follow up eventually cost him his job and reputation. It is still unknown if Paterno knew about other incidents. Cognizant or not, it was surely his business to know of illegal and immoral activity in his locker room. McQueary, it seems, was stuck in Stage IV. He spoke up and followed through. He was led to believe that the situation was under control, but he was not privy to the details. Perhaps he wondered why the police never questioned him in 2002.

The public was confused. Here stood the legendary Joe Paterno, a gentleman whose actions over a lifetime reflected high standards and ethics. He devoted his life to taking care of, nurturing, coaching, and teaching some of the nation's finest youth. How was it that he did not properly handle this situation? He was outspoken, so speaking up and following up should not have been difficult. Even 
more, public confusion ensued after his death in January 2012. How does one grieve during such confusion? One needs only to hop on blog sites to see Paterno's defenders and persecutors lob sharp attacks back and forth. Paterno's 62 years at Penn State are and probably forever will be tainted by this incident. Already, plans to rename Beaver Stadium at Penn State after Paterno have been canceled. He had also been nominated for the Presidential Medal of Freedom, but the nomination has since been withdrawn.

Child abuse stands little tolerance in civilized society. In his writings on sensemaking, Karl Weick (1995) notes that child abuse has always been difficult to recognize, and in the $20^{\text {th }}$ century went ignored for many decades. One explanation for this vacuum was lack of communication between caregivers. Another, however, is much more profound. Adults are supposed to take care of children-that is simply an axiom of the human species' survival. This being the case, it becomes almost impossible to believe that any parent, guardian, teacher, or coach would behave in a manner so inconsistent with their task. For example, Weick found that when doctors were presented with evidence that might lead them to believe a child had been abused by an adult, they tended to dismiss it. So, in trying to make sense of such a confusing, strange situation, people sought alternate explanations. Mrs. Suzanne Paterno, the late coach's wife, told The Washington Post, "We are going to become a more aware society. Maybe we will look for clues." She wonders what signs she missed all those years when they felt so successful and sure of themselves. "I had no clue," she said. "I thought doctors looked for child abuse in a hospital, in a bruise or something" (Jenkins, 2012).

At the end of the day, Joe Paterno, several other officials, and the university president were fired. All the good work they had done over dozens of years was well known, but they were dismissed because they were perceived to have tolerated child abuse. Sandusky, denies the allegations, and the investigation goes on. The tragedy lies in the fact that so much irreversible damage has been done, and healing will be some time coming for the children, for their families, and for Penn State. Many people knew, but action was inadequate.

\section{Gregarious humans: Success by cooperation}

In order to accomplish great tasks (and even small ones), as humans, we optimize by working together. We are a gregarious species. In one way or another, we are all a part of one or several organizations, each of us spinning as a critical gear in an endless system of systems. It follows, then, that we need to coordinate with as well as protect our brothers and sisters of the human race. This is how we evolved to be the planet's most successful species. It was certainly not our brawn as we are out-muscled by countless life forms. It is our ability to cooperate. Indeed, we compete and cooperate symbiotically as teams work with and against each other. As such, knowing our roles in organizations is vital. We constantly balance, deciding when to act and when to sit still, when to speak up and when to listen, when to interfere and when to go with the flow. We do the best we can, but we are not perfect, and we are subject to our limited human intellect as well as learned behaviors from our past successes and failures.

People in large, high-powered organizations who have complicated jobs need to optimize their time and often take shortcuts. 'Did this work before? Then let's do it that way again.' Managers also entrust others with complex tasks. Herbert Simon (1997) calls this satisfycing, a behavior that is necessary in large, complex organizations because managers do not have time or resources to be cognizant of every facet of their charge.

Joe Paterno lived a full, hectic, intense, and busy life. His staff members numbered in the dozens, and his players numbered more than a hundred. He was accustomed to delegating tasks, and he needed to trust his staff as it would not have been possible for him to perform each task required to run a team. Rod Kramer (2009) reminds us that sometimes we trust too much. He asserts that we should trust carefully, periodically verifying what we think we know. In addition, organizations base many of their decisions on experiential learning. Although basing decisions on past experience can be an easy way to proceed, it is not always effective as environments are often dissimilar to those faced by predecessors (March \& Levinthal, 1999). Simply stated, because a method worked in the past, does not mean it will work in the present or the future. However, past practices represent organizational precedent, and going against organizational precedent requires overcoming organizational momentum. In such cases, it is usually risky to speak up and buck the status quo. As a result, organizational actors will often err on the side of the status quo and simply do nothing. Coach Paterno was anything but average. Few people have careers that last 62 years and work well into their $80 \mathrm{~s}$. In his later years, Paterno took a more hands-off approach to coaching. Often due to injuries, he would coach from the press box but would remain in constant communication with his trusted staff on the field. His trust in his staff had 
always worked well for him, so continuing this practice made perfect sense. Paterno selected his staff carefully and deemed them trustworthy.

\subsection{Frustration and fear}

Hardly anything is more frustrating than helplessly watching tragedy unfold. Ordinary events, such as watching someone trip and fall, seeing a loved one become addicted, witnessing a car accident, or extraordinary once-in-a lifetime events, such as living through the eruption of Mt. St. Helens, the terrorist attacks of $9 / 11$, or the recent tsunami in Japan, can fill us with angst. As bystanders, we can only watch small and helpless-sometimes in fear and fascination - unable to change the course. However, what about times when we are able to prevent or divert disaster, but we stand by gawking instead of acting?

This topic came to the fore of social psychology in the wake of the 1964 Kitty Genovese murder, when 33 onlookers watched for some 30 minutes but failed to act as a woman was murdered. Rumblings emerged that cities were becoming places where people, cold and cruel, no longer cared about their fellow human beings. Psychologists John Darley and Bibb Latané were skeptical. Could people really have become that depraved? Darley and Latané set out to collect data on this topic and performed experiments under varying conditions. Their findings were telling. Among a group, people tended to behave like those around them, often believing that their actions were appropriate or that others quite probably knew more. Furthermore, the more ambiguous the situation, the less the group or any single member tended to react. The theory of bystander apathy has been well supported by related studies before and after their work (Darley \& Latané, 1968). Studies since then have told us that people do not act because they are confused in unknown or unique circumstances, although apathy is not totally absent from the equation. In unprecedented situations, we are usually bewildered and thus passive.

\subsection{Altering the course: The benefit of hindsight}

It can be disconcerting to listen to academics prattle on about the optimal path of action with the benefit of hindsight. Without question, knowing what should have been done is much easier than knowing what should be done. However, by carefully examining past situations, studies can draw from scenarios, gleaning commonalities that could be useful in preventing similar errors. While tragedy often happens in differing environments, it is useful to try to learn from our past. In distilling data, patterns may appear that can be an alert to such behavior in the future, potentially preventing disaster or at least mitigating risk. By nature, our lives are full of risk, so risk mitigation is a necessary part of our successful existence. In the next scenario, an unprecedented, ambiguous, misunderstood, unclear, and obfuscated sporting event resulted in the death of a young man.

\section{Nodar Kumaritashvili}

On February 12, 2010, just hours before the opening ceremony of the 2010 Winter Olympic Games in Vancouver Canada, Georgian Olympic luge racer Nodar Kumaritashvili was on a practice run and flew off the high-speed track into a structural pole and to his death. Hearts poured out to his grieving family for the loss of their young son, but many agreed it was an unavoidable tragedy bound to happen in such an inherently dangerous sport. Meanwhile, the events that led up to it revealed something much different.

\subsection{Slow slippage to tragedy}

Backtracking to examine how this event transpired exposes decisions long before the track was built. These dubious decisions affected what would culminate in an exceedingly fast track. The track was designed for speeds of up to 90 miles per hour, but prior to the Olympic Games, the final top-speed estimate was 106. As with chaos theory's notion of sensitivity to initial conditions, where a single decision or small change in the beginning can have enormous effects later, this disaster was born several years before the event (Gleick, 2008). The luge site selection would prove instrumental in a series of decisions that followed. Although the track was originally slated to be built near Vancouver, the Vancouver Olympic Organizing Committee (VANOC) was concerned that a track near the city and coast would be warmer and could become slushy and slow. They selected a narrower and steeper area north of Vancouver in the Whistler Resort area where the weather was consistently colder. Further north, the Olympians, would be guaranteed hard, fast ice. The site dictated narrow, steep, sharp turns, meaning the outcome would be the world's fastest track, which would likely be the venue for record speeds for the luge, bobsled, and other sliding events. To the planners, this promised recordbreaking speeds during the Olympic Games and a track that would attract extreme sports enthusiasts 
from around the globe for many years to come. To the city, an extreme track guaranteed more tourists and financial prosperity far into the future.

Prior to selecting the site, the vice president of the Olympic organizing committee consulted with the International Luge Federation and International Bobsleigh and Tobogganing and considered several possibilities. They consulted a bobsledding expert and former member of Canada's Bobsled Federation, who initially liked the narrower, steeper location but later noted that the site was not ideal. "It would have been nicer if the site would have been wider," he said. Initial concepts were sent to a world-renowned track designer in Germany. The 71-year-old was steeped in experience, having built most of the world's modern bobsled and luge tracks. The track opened for testing in March 2008. During two years of testing, world-class lugers also expressed concern over dangerously high speeds. An Austrian luger noted, "If you start having problems there was nothing you could do [to make corrections] because of the speed." A Polish luger echoed these comments: "It was crazy fast" (Crawford, Albergotti, \& Johnson, 2010).

Nodar Kumaritashvili joined his fellow Olympians for the pre-game test runs. After his death, a new wall and other safety features were added to the track to prevent a recurrence. VANOC gave the family $€ 10,000$ as a small token of their sorrow, but nothing would ever reconcile the young Olympian's untimely death. The family buried him February 20, 2010, before the close of the Vancouver Winter Olympic Games.

\subsection{Inherently dangerous, but safe?}

Who is to blame? Shouldn't someone or at least an organization be held accountable for this tragedy? Warning signals and red flags popped up everywhere prior to the track's completion and even during the two years of testing. While many people and organizations expressed concerns about safety, no one acted effectively. Why? Various people commented on the extreme speed, including the designer, who did not expect the test speeds to exceed 90 miles per hour. Many organizations, experts, and designers had serious concerns about the track but never actually verbalized them until it was too late. Stuck in Stage I of inaction, the players did not know how to revert to a more suitable design. There had not yet been any fatalities on their watch, so as with Paterno, past success was once again working against them.

Psychologist Bob Cialdini (2009) says that humans have developed fixed-action patterns. We have evolved this way to be efficient-able to take mental shortcuts-and not have to continually relearn and reevaluate our plan in similar situations. The behavior he calls social proof is common. Responsibility for this track was spread quite literally around the globe, and accountability was obfuscated. Integral players in the Whistler Sliding Center were warned, but no single organizational player could effectively be the whistleblower. Studies have also suggested that the larger the group, the less likely one is to speak out.

In the design and building of the Whistler Sliding Center, several organizations were responsible for the track design and construction. Communications bounced back and forth for years between these organizations and people scattered around the globe. Language differences and distances confounded communications. The speeds and turns at the Whistler Sliding Center were unprecedented, and where unprecedented activities lurk, so does confusion. When technologies step outside known and comfortable boundaries, people find it impossible to predict outcomes without a standard of comparison. Events unfold and organizational actors may have varying visions of what is to come. As with social proof, people and organizations assume that with so many experts overseeing the process, surely someone would speak up if danger beyond the norm was impending. However, under the momentum of the situation, it would be nearly impossible to stop and reassess. While some of the organizational players occasionally expressed concern, stuck in Stage II, they did not act effectively. As early as March 2009, an attorney for VANOC said that given the warnings, should someone get injured, the case could be made that the committee was warned and did nothing. He also commented that with the Olympics just a year away, he was not sure there was any option to rebuild the track (Dowd, 2012). One could easily speculate it was in the best interest of several entities to keep the track's speeds at a record-breaking level. With all the wrong incentives working against them, the organizational players continued to move in the same direction. This could explain why, in the wake of Kumaritashvili's death, even after adding a wall and some padding, VANOC insisted that the track was safe and that no one had been seriously injured on it in two years of testing. Safe? What does safe mean? Is a luge run ever safe? A world-class luger had just died on their track, and they deemed it safe. As any risk analyst will tell you, the term safe is relative.

So if the track was safe, then why, after Nodar Kumaritashvili's death, did they add an additional wall and padding? Why was the starting point moved lower on the track? More importantly, why weren't these changes made before the Olympics rather than 
after Kumaritashvili's death? The committeeperhaps unwittingly-was playing a little game of risk. Since there had been no deaths in the two years of testing, it would have been difficult to justify track changes. Further, had someone spoken up to suggest changes, it might have been perceived as an admission that the track was not up to Olympic safety standards. Stated or not, VANOC also was motivated to claim the fastest track in history. As it turns out, many people did speak up but not to the point that any effective changes were made.

Like so many other winter sports, luge it is inherently dangerous. With the Whistler Sliding Center, the sport was going through a radical change as the speed increased by an order of magnitude. Further, VANOC's commitment to making the track notoriously fast in order to draw tourists did not keep with the needs of the Olympics.

\subsection{Following the crowd}

I am by no means suggesting that the people involved in creating one of the world's most magnificent sports complexes are incompetent, evil, or sinister. By most measures, the work they did was superb. It is not weird or unusual to expect such a sport to advance as nearly all other sports have (e.g., more advanced equipment as the result of better technology). The cutting edge is part of Olympic-level sports. The many committees, directors, inspectors, and planners were part of a system of checks and balances that often worked well. In fact, they followed a host of safety regulations that were added to the specifications as a result of collective organizational knowledge accumulated over hundreds of years of sledding. This was the fastest and newest track to date, but taking the luge to the next level would require foresight into circumstances yet unknown. While many people involved in planning alluded to concerns about extreme speeds and indicated at least some skepticism, they ultimately went along with the plans. What would have happened if someone had raised a red flag insisting on a reexamination? One can only speculate. VANOC was under nonnegotiable time pressure to have the Whistler Sliding Center ready before the 2010 Winter Olympics. The Olympic dates were not going to change, and it had to be ready. As it was, several people and organizations expressed worries, but construction continued according to plans. For an organizational player it would have been highly risky behavior to stand out. People are not rewarded for preventing accidents as it is impossible to know what disaster might have been averted. The formal system of checks and balances in most large organizations usually evolves as result of learned behaviors and applied knowledge garnered from a history of making mistakes. When people are faced with ambivalent circumstances, they swing with the momentum. Remember from physics that momentum has both mass and direction. With unprecedented track speeds and non-negotiable time pressure, it would have been difficult to alter either one.

For highly complicated projects requiring high specialization, this is a necessary condition and not necessarily a bad one, but it can cause problems. Darley and Latané (1968) found that the more people were involved in observing a situation, the less likely they were to act with sound judgment as accountability was diffused among various groups and, with the groups, various people. So the various experts involved watched the situation degrade until they were forced to make a change.

\section{Can human nature change?}

Going along with others is a behavior resulting from more than two million years of human evolution, for which it has been largely successful. Most of us do it most of the time. The scenarios discussed both beg the question: can human nature change? We seem to know what we have done wrong, but implementing meaningful change is not always possible. Pfeffer and Sutton (1999) suggest that much of our nature prevents us from being capable of lasting implementation. Their studies have shown that many of us exist in a knowing-doing gap: we know what the right course is but fail to follow it. Will we always be afraid to speak against the status quo in large groups? What about those who do? Going against superiors' opinions is usually career-ending. More specific phenomena that perturb good judgment are unprecedented situations and communications confusion, which are discussed next.

\subsection{Unprecedented situation $=$ Confusion}

As discussed earlier, human beings not only rely on each other but on past experience. We take shortcuts so that each time we encounter a situation, we do not have to waste time reevaluating what to do. Most of what we do every day is repetitive, so we do not need to relearn common behaviors. However, when a situation has no precedent, we have to think and decide. We may try to learn through others' experience by watching them, but even situations with precedent often occur in new environments. For most situations, experience is an excellent teacher, but for others, it is not. In ambiguous situations, we have difficulty deciding how to react or behave. We are befuddled and confused. It should 
be noted that at the end of the 1999 football season, Paterno dismissed Sandusky reportedly for poor performance as a coach. It is curious to wonder whether Paterno's keen sense smelled something wrong. Perhaps he actually did not feel that Sandusky could not be trusted.

\subsection{Shooting the messenger}

Another strange phenomenon that likely affects player inaction is the mum effect. That is, organizational actors tend to dilute bad news up the chain of command because no one wants to give the boss bad news. The bearer of the news will likely be blamed regardless of fault. As a result, communications weaken up the chain of command and higher-ups tend to be blind to potentially important information in their organization. Closer to home, readers may recall a childhood incident. Our first thought was 'Who is going to tell Mom?' As children, we knew instinctively that whoever told Mom would be on the receiving end of her wrath, so the common tactic was to simply avoid telling her. Literature shows that shooting the messenger has been deeply engrained in the human psyche, and behavior in modern organizations has revealed this as well. The mum effect results from the messenger making bad news sound not so bad, or worse, not delivering it at all (Pfeffer \& Sutton, 2006). In turn, this causes a roadblock to communication, which can have dire consequences. In the case of Penn State, McQueary was able to rise above his situation. Undoubtedly, it was difficult for him to report what he saw and must have required some fortitude on his part. No one wants to deliver bad news.

\subsection{Moving forward}

Is player inaction a fatal, unchangeable human flaw? If so, how can we possibly move forward? Are we forever subject to the effects inherent in our organizations? How can we learn from history when no two situations or environments are alike? Professor Jim March says that we in fact can learn from history and further that we must (March, Sproull, \& Tamuz 1999). History, he observes, is not always generous with experience, and sample size can be meager. Since ambiguous situations foster mimetic actions, unprecedented situations can create complete confusion. These are dangerous cases in which people are most likely not to speak up but, paradoxically, are when their input is most needed. Risky behavior prevails in many organizations, and even if the tasks are different and the organizations look different, human and organizational misbehavior can and will continue if society does not learn from the past. In order to change this type of culture, mangers will have to consider the following:

- Hold people accountable, including yourself. This is the age-old issue of where the buck stops. Groups and individuals need to be held accountable for their decisions and actions. Ensure your subordinates know the tasks for which they are responsible and then give them the authority to act appropriately. Additionally, ensure they know that they have your support when they fail and that they are comfortable fessing up.

- Do not shoot the messenger. We all do it, and it is the best way to shut down critical communication. Vital information that you need to know lies on the floor of your organization. Your hands-on workers are your best source of data, but they possibly see their input as a criticism of the organization or their hierarchy-the very people who evaluate them. Provide them channels through which to speak up without fear.

- Keep clear and open communication. High communication is essential. While a subordinate should ideally communicate through his/her chain of command, it should not be a hard requirement. There are times when players will have to communicate outside their divisions, and requiring that they 'go through channels' can be hazardous by muddling the message. It can also waste time. With the trend of organizations becoming flatter, channels of communication do not always exist, and organizational players need to communicate through informal channels (Pfeffer, 2010).

- Respect all ideas. If you are fortunate enough to get candid input from your colleagues and subordinates, consider and respect their ideas. Regardless of whether or not you believe the idea has merit, remember that it was given to you at great risk, and the colleague or subordinate who delivered it had to muster up a lot of courage to come to you. If your initial reaction is to dismiss it, reconsider. The late Roger Boisjoly was one of the few 0 ring engineers to speak out against launching Space Shuttle Challenger that cold, wet morning in Florida in January 1986, but his input was not respected. Had his hierarchy taken the time to carefully consider his technical knowledge and opinion, disaster could have been averted.

- Encourage whistleblowers. Keep posing questions to anyone and everyone. This will often require drawing information out of people like parents do out of teenagers who are not always $100 \%$ 
forthcoming. Insist on recommendations from everyone. If you think you may get more information by allowing anonymous input, consider that. Perhaps a secret ballot among VANOC and their partners would have revealed that many people had similar concerns about the track. Secret input is a common tactic to encourage whistleblowing so organizational actors do not fear losing their jobs.

- Listen to your stomach. If something does not seem right, human beings feel it in the gut first. This is not just an expression but an actual physiological reaction to a situation that for some reason seems askew. For example, many humans fear both poisonous and non-poisonous spiders. This irrational behavior is the result of our ancestors who survived by staying away from poisonous spiders. Since it is not often easy to distinguish a poisonous from a harmless spider, our default reaction is to fear all of them. When arachnophobics see a spider, they feel fear in the gut first. Our brain may tell us it is harmless, but it is still nearly impossible to overcome panic. Similarly, organizational players may observe something that does not sit right in their stomachs but is difficult to verbalize.

- Be proactive, not reactive. Encourage those around you to act by being proactive yourself. Always consider best- and worst-case scenarios. If possible, perform quantitative and qualitative risk analysis.

- Alleviate time pressure. There will always be deadlines and pressure to act quickly, but mindfulness that many deadlines are not real is important. Some are merely selected arbitrarily or at a time previously set for a schedule that is no longer relevant, perhaps without knowledge of what might transpire. Nonetheless, effective managers do not give the impression of panic or have a hurried disposition.

\section{Abundantly human}

Sports have become big business even at the amateur level. Similar passive behavior is not uncommon among business and government. Countless tragic events over the past 10 years could have been averted had input been forthcoming and seriously considered.

\subsection{Crisis management}

One such area of research is in the aircraft industry. Now termed captainitis, the tendency for cockpit crew members to not challenge the pilot has been in play in countless aircraft accidents. Captainitis was largely blamed for the deadliest airline crash in history when two 747s collided on the small island of Tenerife in 1977, killing 583 people. While there were numerous factors present, the KLM captain ignored his first officer's reminders that they did not have clearance for takeoff. The captain started down the runway in heavy fog and broadsided the Pan Am 747 that was still on the runway (Weick, 1990).

Another infamous case was the 1982 Air Florida crash into Washington D.C.'s $14^{\text {th }}$ Street Bridge. It was a snowy day in the D.C. area, and the Air Florida 737 was being de-iced in preparation for takeoff from National Airport. Ice on aircraft wings has an adverse effect on lift and speed. As the aircraft was rolling down the runway, the first officer told the captain three times that the speed did not seem right, but the captain dismissed him. The 737 indeed lacked adequate lift, hit the $14^{\text {th }}$ Street Bridge, crashing into the Potomac River and killing nearly everyone on board (Kayten, 1993). There are countless other accounts of accidents in which players were intimidated by the boss and did not ensure their input was taken seriously. The Air Force and commercial airlines have studied captainitis extensively, and there are even training seminars tasked to teach copilots how to speak up and captains how to better encourage input and listen.

In recent disasters, such as the Costa Concordia sinking and the BP Deepwater Horizon explosion, one cannot help but wonder if crew members had insight into what was about to happen; perhaps they even spoke up but were not heard. These cases are ongoing, but better crisis management was clearly needed in each of the aforementioned situations.

\section{Conclusion}

Surely, we are all abundantly human, and organizations are resilient to cultural change. Who could have believed that in the highly respected Penn State football program, there could be wrongdoing as bizarre as child abuse? This is an organization that exists for the wellbeing of young people. As well, in inherently dangerous sports, such as luging, there will surely be accidents in the future, some perhaps that should have been prevented. Pushing the outer envelope is a part of who we are. We compete in athletic and all kinds of other events, risking life and limb because we are driven by nature. In our innate drive, however, we are inclined to overlook obvious dangers for all the reasons outlined here. To overcome irrational behavior, we need to step back, take a breath, think rationally, and-most importantly-have the 
patience to listen to others as well as the courage to speak up.

\section{References}

Carey, J. (2012, January 23). Penn State coaching legend Joe Paterno dies at 85. USA Today. Retrieved from http://usatoday30. usatoday.com/sports/college/football/story/2012-01-21/ former-penn-state-coach-joe-paterno-dead/52737230/1

Cialdini, R. B. (2009). Influence: Science and practice $\left(5^{\text {th }}\right.$ ed.). Upper Saddle River, NJ: Pearson.

Crawford, D., Albergotti, R., \& Johnson, I. (2010, February 16). Speed and commerce skewed track's design. The Wall Street Journal. Retrieved from http://online.wsj.com/article/ SB10001424052748704804204575069753617335586.html

Darley, J. M., \& Latané, B. (1968). Bystander intervention in emergencies: Diffusion of responsibility. Journal of Personality and Social Psychology, 8(4/1), 377-383.

Dowd, A. (2012, February 7). New questions about 2010 Vancouver luge death. Retrieved November 18, 2011, from http://www. reuters.com/article/2011/02/07/us-olympics-vancouverluger-idUSTRE7165VD20110207

Everson, D. (2012, January 22). Joe Paterno dies at 85. The Wall Street Journal, January 22. Retrieved from http://online. wsj.com/article/SB10001424052970203750404577175892468 065470.html

Gay, J. (2012, January 22). Paterno's unsettled goodbye. The Wall Street Journal. Retrieved from http: / /online.wsj.com/article/ SB10001424052970203718504577177170352871362.html

Gleick, J. (2008). Chaos theory. New York: Penguin Books.

Jenkins, S. (2012, January 14). Joe Paterno's last interview. The Washington Post. Retrieved from http://articles. washingtonpost. com/2012-01-14/sports/35438962_1_paterno-jerry-sanduskyuniversity-procedure

Kayten, P. J. (1993). The accident investigator's perspective. In E. L. Weiner, B. G. Kanki, \& R. L. Helmreich (Eds.), Cockpit resource management (pp. 283-314). Waltham, MA: Academic Press.

Kingkade, T. (2011, November 9) Penn State scandal timeline: key dates in the Jerry Sandusky sex abuse case. The Huffington Post. Retrieved from: http://www.huffingtonpost.com/2011/ 11/09/penn-state-scandal-timeline-jerry-sandusky_n_ 1084204.html

Kramer, R. (2009). Rethinking trust. Harvard Business Review, 87(6), 68-77.

March, J. G. \& \& Levinthal, D. A. (1999). The myopia of learning. In J. March (Ed.), The pursuit of organizational intelligence (pp. 193-221). Malden, MA: Blackwell.

March, J. G., Sproull, L. S., \& Tamuz, M. (1999). Learning from examples of one or fewer. In J. March (Ed.), The pursuit of organizational intelligence (pp. 137-155). Malden, MA: Blackwell.

Pfeffer, J. (2010). Power play. Harvard Business Review, 88(7/8), 84-92.

Pfeffer, J., \& Sutton, R. I. (1999). The knowing-doing gap: How smart companies turn knowledge into action. Boston, MA: Harvard Business School Press.

Pfeffer, J., \& Sutton, R. I. (2006). Hard facts, dangerous halftruths, and total nonsense. Boston, MA: Harvard Business School Press.

Simon, H. A. (1997). Administrative behavior. New York: Free Press.

Weick, K. E. (1990). The vulnerable system: An analysis of the Tenerife air disaster. Journal of Management, 16(3), 571-593.

Weick, K. E. (1995). Sensemaking in organizations. Thousand Oaks, CA: Sage. 